Modi $\mathrm{f} i$ cat $\mathrm{i}$ on of ther mosensitivity by am ubi ci $n$ or am ubi ci nol i n human I ung adenocar ci noma A549 cel Is and the ki neti cs of apoptosi s and necr osi s i nduct i on

\begin{tabular}{|c|c|}
\hline 著者 & $\begin{array}{l}\text { HAYASH Sachi ko, HATASH TA Nasanori, MATSUMOTO } \\
\text { Hi deki, Ji n Zhao- Hui, SH OURA Hi roki, KANO } \\
\text { Ei i chi }\end{array}$ \\
\hline $\begin{array}{l}\text { jour nal or } \\
\text { publ i cat } i \text { on } \mathrm{title}\end{array}$ & I nt er nat i onal J our nal of $\mathrm{M}$ l ecul ar Medi ci ne \\
\hline vol une & 16 \\
\hline page $r$ ange & $381-387$ \\
\hline year & 2005- 05 \\
\hline URL & ht t p: //hdl . handl e. net /10098/1070 \\
\hline
\end{tabular}




\title{
Modification of thermosensitivity by amrubicin or amrubicinol in human lung adenocarcinoma A549 cells and the kinetics of apoptosis and necrosis induction
}

\author{
SACHIKO HAYASHI ${ }^{1}$, MASANORI HATASHITA ${ }^{3}$, HIDEKI MATSUMOTO ${ }^{1}$, \\ ZHAO-HUI JIN $^{1}$, HIROKI SHIOURA ${ }^{2}$ and EIICHI KANO ${ }^{1}$ \\ Departments of ${ }^{1}$ Experimental Radiology and Health Physics, ${ }^{2}$ Radiology, Faculty of Medical Science, \\ Fukui University, Matsuoka, Fukui 910-1193; ${ }^{3}$ The Wakasawan Energy Research Center, \\ Research and Development Department, Tsuruga 914-0192, Japan
}

Received March 31, 2005; Accepted May 16, 2005

\begin{abstract}
The effects of amrubicin (AMR) and its active metabolite, amrubicinol (AMROH), on the sensitivity of human lung adenocarcinoma A549 cell line to hyperthermia at $44^{\circ} \mathrm{C}$ were investigated. The cell phase response as well as the kinetics of apoptosis and necrosis induction were also analyzed. The cytocidal effects of $44^{\circ} \mathrm{C}$ hyperthermia on A549 cells exhibited low thermosensitivity with a $T_{0}$ value of $12 \mathrm{~min}$. The slope of the survival curve in the exponential phase, described semilogarithmically, in $44^{\circ} \mathrm{C}$ hyperthermia combined treatment with AMROH $(0.02 \mu \mathrm{g} / \mathrm{ml})$ was approximately parallel to $44^{\circ} \mathrm{C}$ hyperthermia alone. The initial shoulder shape portion of the survival curve from $44^{\circ} \mathrm{C}$ hyperthermia alone, indicating the repair of sublethal thermal damage (SLTDR), was reduced with the sequential combined treatment of AMR or AMROH. Sequential treatments with AMR or AMROH prior to $44^{\circ} \mathrm{C}$ hyperthermia resulted in additive thermo-enhancement effect by reducing not only survival but was shoulder wide. Furthermore, like AMR and AMROH, adriamycin (ADM) and etoposide (VP-16) are DNA topoisomerase II inhibitors, and the effects of these 4 agents on $44^{\circ} \mathrm{C}$ hyperthermia were compared. All 4 agents exhibited comparable thermo-enhancement effects. Using synchronized A549 cells, AMR or AMROH did not elicit cell phase responses, irrespective of the concentration. The induction of apoptosis was investigated at 48 and $72 \mathrm{~h}$ after AMROH treatment, $44^{\circ} \mathrm{C}$ hyperthermia or the combined treatment, in which apoptosis was not significantly induced after any treatment. Furthermore, the incidence of necrosis was
\end{abstract}

Correspondence to: Dr Sachiko Hayashi, Department of Experimental Radiology, Faculty of Medical Science, Fukui University, Matsuoka, Fukui 910-1193, Japan

E-mail: hayashis@fmsrsa.fukui-med.ac.jp

Key words: amrubicin, human lung adenocarcinoma A549 cells, hyperthermia, thermosensitivity, cell phase response, apoptosis, necrosis, topoisomerase II examined as well as apoptosis. The incidence of necrosis at 48 and $72 \mathrm{~h}$ after AMROH was 2.4 and $4.3 \%$, respectively; after $44^{\circ} \mathrm{C}$ hyperthermia was 3.3 and $4.0 \%$, respectively; and after the combined treatment it was 10.7 and $8.7 \%$, respectively. The necrosis induced after the combined treatment was circa 3 times higher than that in either of the single treatments.

\section{Introduction}

Amrubicin hydrochloride (AMR) is the first totally-chemically synthesized anthracycline derivatives $(1,2)$. and it exhibits antitumor activity against human non-small cell lung, small cell lung and superficial bladder cancer (3-5). AMR exerts its antitumor effects by inhibiting topoisomerase II activity and suppressing DNA synthesis $(6,7)$. AMR is metabolized to AMROH in vivo (2), and the results of our in vitro study using human lung cancer A549 cells cridenced that the cytocidal effects of AMROH were about 10 times more potent than those of AMR. The survival curves of A549 cells treated with isotoxic doses of AMR and AMROH showed the same profile. When cancer cells are exposed to hyperthermia, the cells usually acquire thermo-tolerance during heating or afterwards, which has been one of the problems associated with thermotherapy (8-10). Thermo- and chemo-therapy, a combined treatment with hyperthermia and chemical agents, has been adopted as an interdisciplinary treatment strategy to overcome the problems of thermotolerance.

We previously reported that the lethal sensitivity in the simultaneous combined treatment with $42^{\circ} \mathrm{C}$ hyperthermia and adriamycin (ADM) for the initial short time was markedly higher but followed by reduced lethal sensitivity, the sequential treatment showed the tolerant lethal sensitivity (11). In this study, the modification of thermo-sensitivity by AMR or AMROH was investigated using A549 cells in vitro. A549 cell line originating from human lung adenocarcinoma was established by Giard et al $(12,13)$. Several studies have been conducted on the sensitivity of A549 cells to radiation and hyperthermia (14-17).

It has been clarified at the molecular level that A549 cells have a mutated K-ras gene (18) and the wild-type p53 gene (19). When DNA is damaged, wild-type p53 protein is 


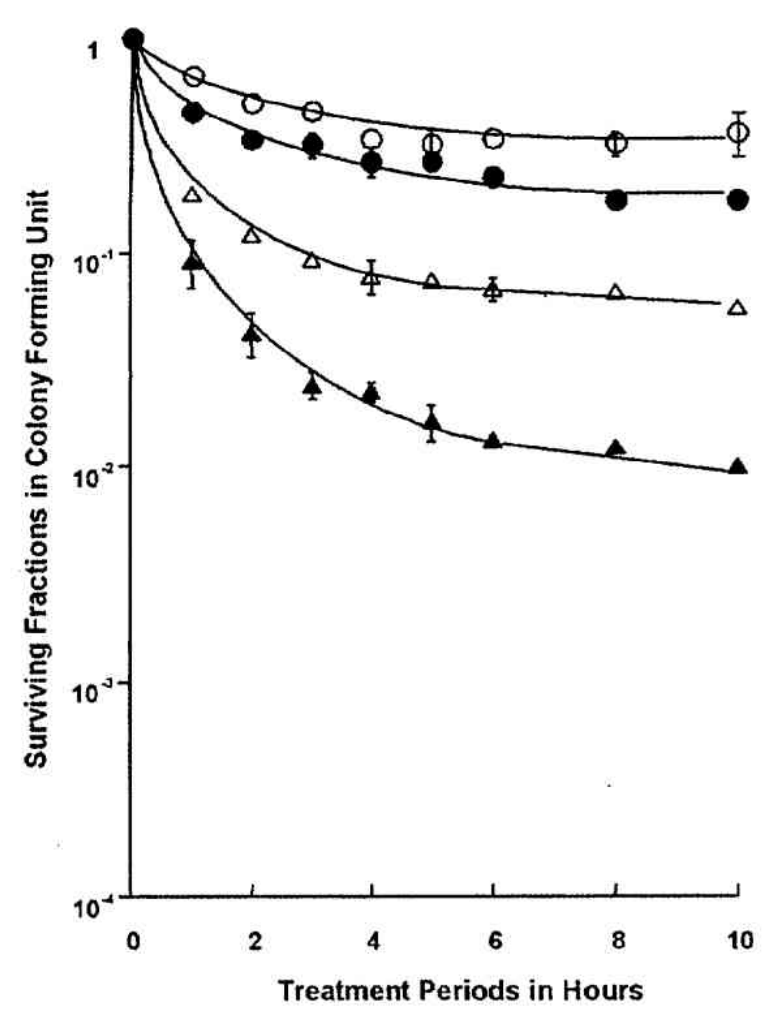

Figure 1. Cytocidal effect of AMROH in graded concentration on survival of A549 cells. Ordinate: log surviving fractions (SFs) in colony forming unit. Abscissa: treatment periods of AMROH in hours. Symbols of the survival curve represent the concentration of AMROH in open circles $(0.01 \mu \mathrm{g} / \mathrm{ml})$, closed circles $(0.02 \mu \mathrm{g} / \mathrm{ml})$, open triangles $(0.1 \mu \mathrm{g} / \mathrm{ml})$ and closed triangles $(0.2 \mu \mathrm{g} / \mathrm{ml})$, respectively. Symbols with vertical bars represent means with standard errors obtained from three independent SFs. Symbols without a bar represent the standard error within the symbols.

activated by phosphorylation on signaling pathway, and the activated p53 exhibits antitumor effects by inducing either apoptosis or $\mathrm{G}_{1}$ arrest (20-25). The ras gene was one of the first oncogenes discovered, and it is involved in cellular proliferation and differentiation (26-28), but there have not been any studies investigating the relationship between the ras gene and thermosensitivity.

In the present study, we analyzed the effects of AMR and AMROH on the thermosensitivity of A549 cells with the above-mentioned genetic backgrounds. We examined the thermo-enhancement effects of isotoxic doses of AMR and AMROH on the sensitivity of A549 cells to $44^{\circ} \mathrm{C}$ hyperthermia and compared the effects of AMR and AMROH with those of two other DNA topoisomerase II inhibitors (ADM and VP-16). With regard to cell phase responses to hyperthermia, the survival curve for mild hyperthermia at $40^{\circ} \mathrm{C}$ was flat and responses were not appreciable for any phase (16), but the responses for experimental hyperthermia at $44^{\circ} \mathrm{C}$ showed marked cytotoxicity in the $\mathrm{S}$ phase $(30,31)$.

We conducted a study using bleomycin, a DNA synthesis inhibitor, and confirmed that the survival curve for synchronized cells was flat regardless of drug concentration, and that cell phase responses were not appreciable during cell phase progression (30). The cell phase responses to AMR and AMROH have not been clarified. Therefore, we investigated the cell phase responses of A549 cells synchronized with

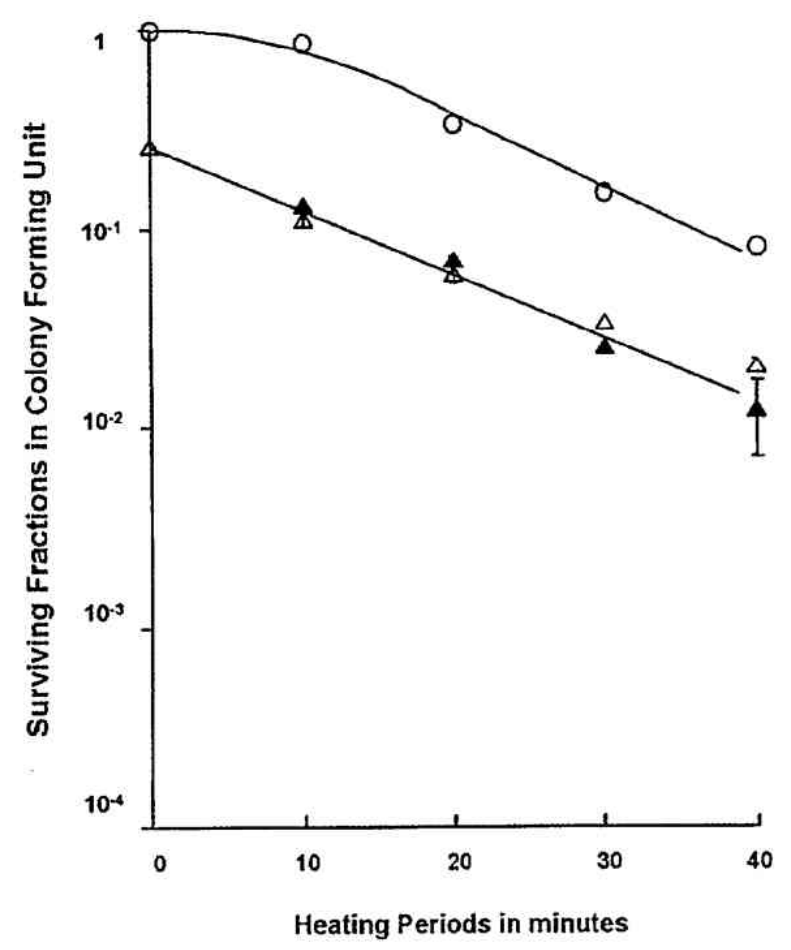

Figure 2. Effect of thermo-enhancement of AMR $(0.2 \mu \mathrm{g} / \mathrm{ml})$ in A549 cells. Ordinate: log surviving fractions (SFs) in colony forming unit. Abscissa: heating periods at $44^{\circ} \mathrm{C}$ in minutes. Open circles represent SFs of cells from $44^{\circ} \mathrm{C}$ hyperthermia alone. Open triangles represent SFs of cells treated with hyperthermia at $44^{\circ} \mathrm{C}$ for graded periods followed by AMR for $3 \mathrm{~h}$. Closed triangles represent SFs of cells from hyperthermia at $44^{\circ} \mathrm{C}$ for graded periods after pre-treatment with AMR for $3 \mathrm{~h}$. Symbols with vertical bars represent means with standard errors obtained from three independent SFs. Symbols without a bar represent the standard error within the symbols.

hydroxyurea to AMR and AMROH. In murine $\mathrm{L}$ cells having wild-type p53 that show high thermosensitivity, hyperthermia effectively induced apoptosis (8).

Here, in A549 cells that have wild-type p53 gene and are not thermosensitive, the induction of apoptosis $(32,33)$ and necrosis $(34,35)$ was investigated following $\mathrm{AMROH}$ treatment combined sequentially with $44^{\circ} \mathrm{C}$ hyperthermia. The effects of AMR and its active metabolite, AMROH, on the sensitivity of A549 cells to $44^{\circ} \mathrm{C}$ hyperthermia were analyzed at the kinetic and molecular levels.

\section{Materials and methods}

Cells and culture medium. A549, a human lung adenocarcinoma cell line, cultured in Eagle's minimum essential medium (Nissui Pharmaceutical, Tokyo, Japan) containing NCTC-135 (Gibco Laboratories, Grand Island, NY, USA), lactalbumin hydrolysate solution (Difco Laboratories, Detroit, USA) and $15 \%$ newborn calf serum (Gibco) (hereinafter referred to as MLN-15), was used $(12,13)$.

Chemicals, hyperthermia and treatments. AMR or AMROH (Sumitomo Pharmaceuticals Co., Ltd. Osaka, Japan) was dissolved in the culture medium to an appropriate final concentration for the treatment. The adhered cells in the flasks were treated with AMR or AMROH by replacement with $6 \mathrm{ml}$ of the AMR or AMROH solution in MLN-15 for graded 


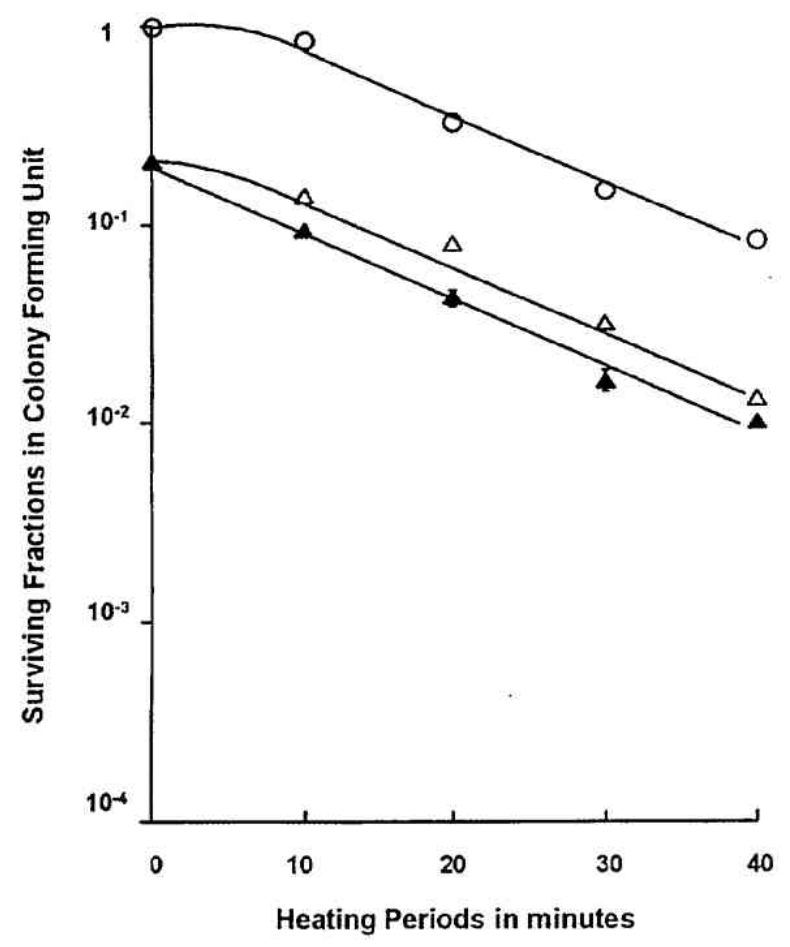

Figure 3. Effect of thermo-enhancement of AMROH $(0.02 \mu \mathrm{g} / \mathrm{ml})$ in A549 cells. Ordinate: $\log$ surviving fractions (SFs) in colony forming unit. Abscissa: heating periods at $44^{\circ} \mathrm{C}$ in minutes. Open circles represent SFs of cells from $44^{\circ} \mathrm{C}$ hyperthermia alone. Open triangles represent SFs of cells treated with hyperthermia at $44^{\circ} \mathrm{C}$ for graded periods followed by AMROH for $3 \mathrm{~h}$. Closed triangles represent SFs of cells from hyperthermia at $44^{\circ} \mathrm{C}$ for graded periods after pre-treatment with AMROH for $3 \mathrm{~h}$. Symbols with vertical bars represent means with standard errors obtained from three independent SFs. Symbols without a bar represent the standard error within the symbols.

periods. After the exposure to AMR or AMROH, the atdhered cells were chased, gently rinsed twice and re-fed with $6 \mathrm{ml}$ of the culture medium. MLN-15. Thus, treated flasks were incubated stationarily for visible colony formation.

Hyperthermia was carried out by immersion of culture flasks of the tightened screw tops in a temperature-regulated water bath (Model EPS-47, Tokyo Seisakusho Co., Tokyo, Japan) pre-set at $44^{\circ} \mathrm{C}$. The temperature was maintained within the error of $\pm 0.05^{\circ} \mathrm{C}$ as measured with a thermistor (Model DI16-1251, Takara Thermistor Instruments Co., Yokohama, Japan).

For combined treatment with chemotherapy and thermotherapy were carried out sequentially. Cells treated with AMR or AMROH for $3 \mathrm{~h}$ were rinsed twice with culture medium containing 3\% serum, placed in MLN-15 and followed by $44^{\circ} \mathrm{C}$ hyperthermia. Kinetic assessment of the sensitivity of A549 cells to agents and hyperthermia was carried out by the colony formation method and corrected based on the plating efficiency of the control (i.e., 80-90\%). The average colony multiplicity was $<1.1$. The $T_{0}$ value, adopted as the criterion of cellular thermo- or chemo-sensitivity, represented the treatment period required to reduce survivals by $1 / \mathrm{e}$ in the exponentially regressing portion of the survival curves, i.e., the linear portions of the treatment period in survival curves semilogarithmically.
For cell phase responses, A549 cells were treated with $4 \mathrm{mM}$ hydroxyurea (HU) (Sigma Chemical, St. Louis, MO, USA) $(36,37)$ for $5 \mathrm{~h}$ to synchronize them at the $\mathrm{G}_{1}$-S border, and after an interval of $1-9 \mathrm{~h}$, cells were treated with AMR or AMROH for $4 \mathrm{~h}$. Cell phase responses were also analyzed by the colony formation methods.

Analysis of apoptosis and necrosis. Induction of apoptosis was analyzed at 48 and $72 \mathrm{~h}$ after treatment with $0.02 \mu \mathrm{g} / \mathrm{ml}$ AMROH for $4 \mathrm{~h} .44^{\circ} \mathrm{C}$ hyperthermia for $35 \mathrm{~min}$, or the combined treatment. Trypsinized cells were placed in MLN-15 to stop trypsinization, rinsed with PBS(-), fixed overnight in 1\% glutaraldehyde (Nacalai Tesque Inc., Kyoto, Japan), and placed in PBS(-). For observation, cells were stained with $0.2 \mathrm{mM}$ Höchst 33342; Bisbenzimide H33342 Fluorochrome, Trihydrochloride (Calbiochem, Merck KGoA, Dormstodt, Germany) and were analyzed under a fluorescence microscope (Nikon Eclipse E600, Nikon Co. Lid, Tokyo, Japan). A total of 1,000 cells were counted, and the percentage of typical apoptotic cells was calculated. The induction of necrosis was also determined after the above-described treatments. After doublestaining the cells using acridine orange (Sigma-Aldrich Co. St. Louis, USA) and ethidium bromide (Nacalai Tesque Inc., Kyolo, Japan) (AO/EB) (38), cells were observed in real-time under a fluorescence microscope, and the percentage of typical necrotic cells was calculated.

\section{Results}

Cytotoxic effects of AMROH. A549 cells were treated with graded concentrations of AMROH $(0.01,0.02,0.1$ or $0.2 \mu \mathrm{g} /$ $\mathrm{ml}$ ) for $1-10 \mathrm{~h}$ in order to determine its cytotoxic effects as shown in Fig. 1. For each concentration, the surviving fraction of cells were plotted against treatment time on a semilogarithmic chart. All curves showed steeply a slope during the initial stages of treatment. At concentrations of 0.01 and $0.02 \mu \mathrm{g} / \mathrm{ml}$, the curves gradually reached a plateau after 4 to $6 \mathrm{~h}$, and the plateau was maintained $\leq 10 \mathrm{~h}$ at all concentrations. AMROH was markedly cytotoxic during the early stages of treatment, but no marked changes in sensitivity were seen beyond $4 \mathrm{~h}$.

Heating period $\left(44^{\circ} \mathrm{C}\right)$ - survival relationships of $A 549$ cells. With regard to the thermosensitivity of A549 cells, the $T_{0}$ value (dose required to reduce the survival by $1 / \mathrm{e}$ ), which is the reciprocal of the slope of the survival curve in the exponential phase, was $12 \mathrm{~min}$ for $44^{\circ} \mathrm{C}$ hyperthermia. As is the case with the Elkind recovery associated with low-dose radiotherapy, the repair of sublethal thermal damage (SLTDR), which is seen as a curve shoulder, was identified during the early stages of hyperthermia. The $\mathrm{Tq}$ value, a sort of cellular capacity for SLTDR, was $6.5 \mathrm{~min}$ as shown in Fig. 2.

The effects of AMROH on hyperthermia. Using A549 cells, the thermo-enhancement effects of AMR and AMROH were investigated based on the survival curves drawn after $44^{\circ} \mathrm{C}$ hyperthermia and AMROH combination therapy in Figs. 2 and 3. The survival curve of the cells performed with $44^{\circ} \mathrm{C}$ hyperthermia alone elicited a shoulder, indicating the repair of SLTD, whereas the curve of sequentially combined 
Table I. Comparison of thermo-enhancement by four topoisomerase II inhibitors.

\begin{tabular}{lccc}
\hline & $\begin{array}{c}44^{\circ} \mathrm{C} \text { alone } \\
\mathrm{T}_{0}\end{array}$ & $\begin{array}{c}\text { Chemical }-44^{\circ} \mathrm{C} \\
\mathrm{T}_{0}\end{array}$ & $\begin{array}{c}\text { Enhancement } \\
\text { ratio }\end{array}$ \\
\hline AMR & 1.40 & 1.05 & 1.33 \\
AMROH & 1.40 & 1.00 & 1.40 \\
ADM & 1.40 & 1.05 & 1.33 \\
VP-16 & 1.40 & 0.95 & 1.47 \\
\hline
\end{tabular}

The thermo-enhancement effects to $44^{\circ} \mathrm{C}$ hyperthermia of 4 agents in DNA topoisomerase II inhibitor, AMR, AMROH, ADM and VP-16, were compared by $T_{0}$ value. The A549 cells were treated with agent prepared at isotoxic dose, AMR $(2.5 \mu \mathrm{g} / \mathrm{ml})$, AMROH $(0.02 \mu \mathrm{g} / \mathrm{ml})$, ADM $(0.02 \mu \mathrm{g} / \mathrm{ml})$ or VP- $16(2.0 \mu \mathrm{g} / \mathrm{ml})$ for $3 \mathrm{~h}$ respectively and followed by hyperthermia at $44^{\circ} \mathrm{C}$ for $30 \mathrm{~min}$ in the combined treatment.

treatment with AMR or AMROH was reduced. The SLTDR associated with short-term hyperthermia was blocked by AMR or AMROH. The slope of the survival curve in the exponential phase for $44^{\circ} \mathrm{C}$ hyperthermia and the combination therapy with AMR or AMROH were parallel, i.e. administration of AMR or AMROH prior to hyperthermia showed additive thermo-enhancement effects. The thermoenhancement eflects of 4 topoisomerase II inhibitors. ADM, VP-16, AMR and AMROH, on $44^{\circ} \mathrm{C}$ hyperthermia for $30 \mathrm{~min}$ were compared as shown in Table I. The effects of 4 agents in isotoxic doses were comparable, markedly enhancing the effects of hyperthermia.

Cell phase responses to AMR and AMROH. A549 cells synchronized at the $\mathrm{G}_{1}-\mathrm{S}$ border by treatment with $4 \mathrm{mM} \mathrm{HU}$ for $5 \mathrm{~h}$ were incubated for graded periods of time, and were further exposed to AMR and AMROH in order to analyze the cell phase responses as shown in Fig. 4. As a control, synchronized cells were incubated for graded periods of time and were treated with $4 \mathrm{mM}$ HU for $2 \mathrm{~h}$, not shown in the figure. Cell survival was plotted in order to compare the results with the standard cell-cycle phase. After a specified interval, synchronized A549 cells were treated with 3 graded concentrations of AMR or AMROH for $4 \mathrm{~h}$ respectively, and the survival curve was largely flat for all cell-cycle phases at all concentrations. AMR and AMROH did not elicit cell phase responses, irrespective of the concentration.

Effects on apoptosis induction. The thermo-enhancement effects of AMROH on A549 cells were investigated based on the induction of apoptosis as shown in Fig. 5. After AMROH for $4 \mathrm{~h}, 44^{\circ} \mathrm{C}$ hyperthermia for $35 \mathrm{~min}$ or combination therapy, cells were harvested at 48 and $72 \mathrm{~h}$ after incubation and were fixed with glutaraldehyde. Fixed cells were stained with Höchst 33342 solution, and cellular morphology was observed under a fluorescence microscope in order to determine the percentage of apoptotic cells. At 48 and $72 \mathrm{~h}$ after treatment with AMROH alone, the incidence of apoptosis was $0.9 \%$ and $1 \%$, respectively; circa $1.3 \%$ (at both time points) for $44^{\circ} \mathrm{C}$

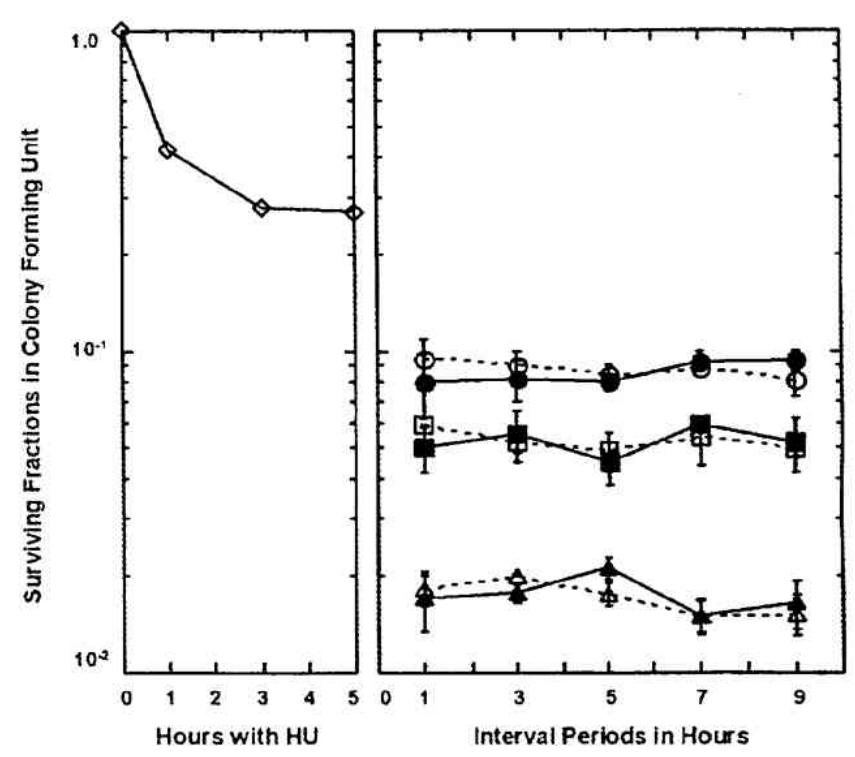

Figure 4. Left panel shows the HU treatment period-survival relationship of cells. Right panel shows the cell phase responses to AMR or AMROH in gradational concentration for A549 cells synchronized by the exposure to HU for $5 \mathrm{~h}$. Ordinates: $\log$ surviving fractions (SFs) in colony forming unit. Abscissa in left panel: teatment periods with $4 \mathrm{mM} \mathrm{HU}$ in hours. Abscissa in right panel: incubation periods at $37^{\circ} \mathrm{C}$ between the pre-treatment with HU for $5 \mathrm{~h}$ and the post-Ireatment with AMR or AMROH for $4 \mathrm{~h}$. Open circles, open squares and open triangles represent SFs from post-treatment with AMR in $0.1,0.5$ and $2.5 \mu \mathrm{g} / \mathrm{ml}$, respectively. Closed circles, closed squares and closed triangles represent SFs from post-treatment with AMROH in $0.004,0.02$ and $0.1 \mu \mathrm{g} / \mathrm{ml}$, respectively. Symbols with vertical bars represent means with standard errors obtained from three independent SFs. Symbols without a bar represent the standard error within the symbols.

hyperthermia alone; and 2.4 and $1.7 \%$ for combination therapy, respectively.

Effects on necrosis induction. As was the case with apoptosis. the thermo-enhancement effects of AMROH on A549 cells were investigated in the induction of necrosis. The incidence of necrotic cells following AMROH treatment, $44^{\circ} \mathrm{C}$ hyperthermia or the combination therapy was investigated by $\mathrm{AO} /$ EB double staining at intervals of 48 and $72 \mathrm{~h}$ after treatment. The incidence of necrosis at 48 and $72 \mathrm{~h}$ after treatment with $\mathrm{AMROH}$ was 2.4 and $4.3 \%$, respectively, after $44^{\circ} \mathrm{C}$ hyperthermia was 3.3 and $4.0 \%$, respectively, and after combined treatment it was 10.7 and $8.7 \%$, respectively as shown in Fig. 6.

\section{Discussion}

In the present study, the modilication of AMR and AMROH on the thermosensitivity of A549 cells was investigated.

Cytotoxicity of AMROH. In our study, AMROH exhibited marked cytotoxic activity during the early stages. AMR and its active metabolite, AMROH, are DNA topoisomerase II inhibitors $(3,4)$. DNA topoisomerase II is reported to be vital for essential biological reactions such as replication, transcription and genetic recombination (39-41). In 1984, Liu et al discovered that mAMSA [4'-(9-acridinylamino) methanesulfon$\mathrm{m}$-anisidide], an antitumor agent, inhibited topoisomerase II 


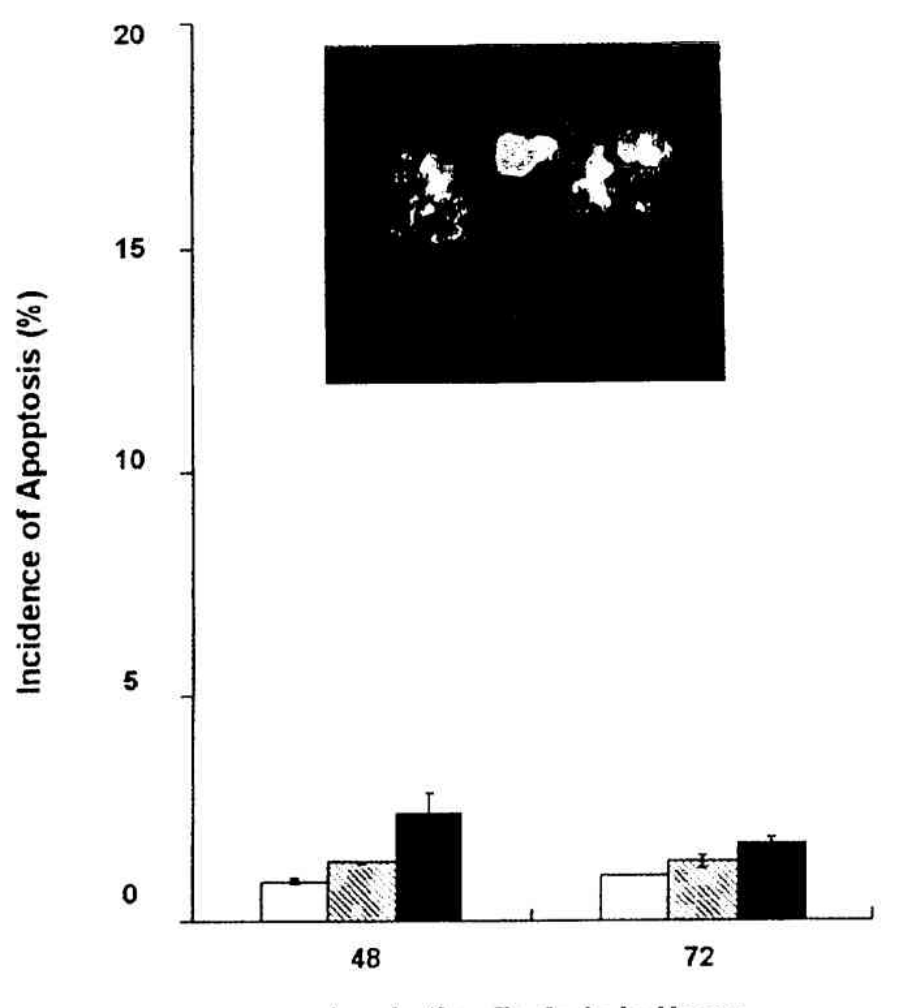

Incubation Periods in Hours

Figure 5. Kinetics of apoptosis induction at 48 or $72 \mathrm{~h}$ of incubation periods after AMROH, $44^{\circ} \mathrm{C}$ hyperthermia or the combined treatment. At indicated time, A549 cells stained with Höchst 33342 were observed under a fluorescent microscope. The cells of DNA fragmented nuclei with typical morphological features of apoptosis were counted as apoptotic cells. Ordinate: percentages of apoptosis in the total cells. Abscissa: $37^{\circ} \mathrm{C}$ incubation periods in hours after treatment. Columns represent AMROH $(0.02 \mu \mathrm{g} / \mathrm{ml})$ for $4 \mathrm{~h}, 44^{\circ} \mathrm{C}$ hyperthermia for $35 \mathrm{~min}$ and the combined treatments in order from the left, respectively. Incidence of apoptosis after treatment with AMROH or hyperthermia alone were slightly induced in interval periods at 48 and $72 \mathrm{~h}$. In the combined treatment, no frequency of apoptosis increased significantly.

in mammals (42). Therefore, topoisomerase II inhibitors are effective anticancer agents because topoisomerase II inactivation and inhibition severely affect cell survival $(43,44)$.

Effects on hyperthermia. When A549 cells were treated with AMR or AMROH prior to $44^{\circ} \mathrm{C}$ heating in vitro, the SLTDR seen during the early stages of hyperthermia was inhibited. AMR and AMROH additively enhanced the effects of $44^{\circ} \mathrm{C}$ hyperthermia. In thermotherapy for cancer, the time required to achieve $10 \%$ survival $(0.1$ on a survival curve) for hyperthermia alone was $30 \mathrm{~min}$, but that for the combination therapy was $10 \mathrm{~min}$. Comparable results were obtained in about one-third of the time by combining hyperthermia with AMR or AMROH. The fact that combining AMR or AMROH cuts the duration of hyperthermia to one-third is beneficial in multidisciplinary anticancer therapy. We have investigated the ability of various chemicals to modify the effects of hyperthermia using different cells at the kinetic and molecular levels $(11,30,45-47)$. The effects of AMR, AMROH, ADM (48) and VP-16 (49), which target DNA metabolism, on the thermosensitivity of A549 cells were compared. When A549 cells were treated with isotoxic doses of AMR, AMROH,

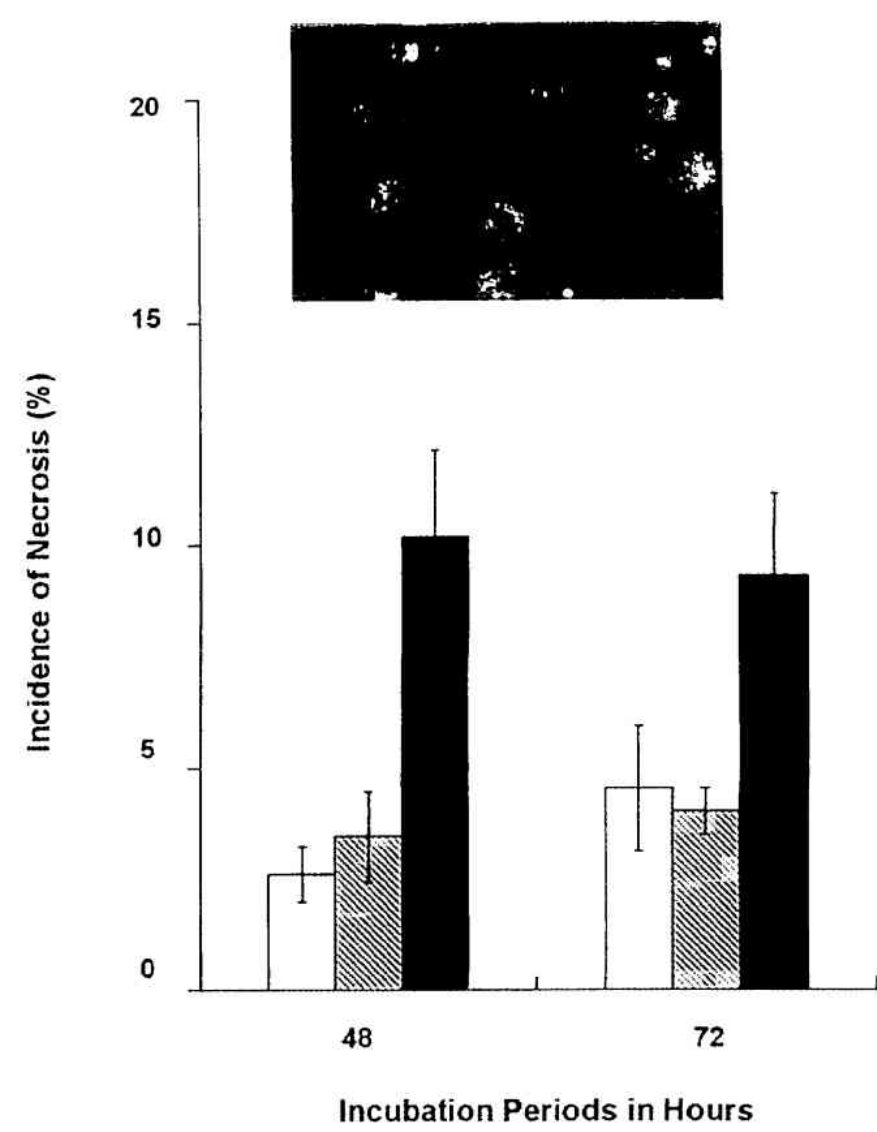

Figure 6. Kinetics of necrosis induction at 48 or $72 \mathrm{~h}$ of incubation periods after AMROH, $44^{\circ} \mathrm{C}$ hyperthermia or the combined treatment. At indicated lime, A549 cells by double staining with $\mathrm{AO} / \mathrm{EB}$ were observed under a fluorescent microscope. The rubious cells were counted as necrotic cells. Ordinate: percentages of necrosis in the total cells. Abscissa: $37^{\circ} \mathrm{C}$ incubation periods in hours alter treatment. Columns represent AMROH $(0.02 \mu \mathrm{g} / \mathrm{ml})$ for $4 \mathrm{~h}, 44^{\circ} \mathrm{C}$ hyperthermia for $35 \mathrm{~min}$ and the combined treatments in order from the left. respectively. Incidences of necrosis after AMROH or hyperthermia alone were both induced slightly in interval periods at 48 and $72 \mathrm{~h}$. In these combined treatment, the frequency of necrosis increased significantly.

ADM or VP- 16 for $3 \mathrm{~h}$ and then sequentially subjected to $44^{\circ} \mathrm{C}$ hyperthermia for $30 \mathrm{~min}$, comparable degrees of enhancement were noted. These lindings clarify that all topoisomerase II inhibitors increase the thermosensitivity of A549 cells.

Cell phase responses. In order to clarily the mechanisms of thermal enhancement by AMR or AMROH, we investigated the survival curves through cell phase progression, the cell phase response of A549 cells to $0.1,0.5$ and $2.5 \mu \mathrm{g} / \mathrm{ml}$ of AMR or $0.004,0.02$ and $0.1 \mu \mathrm{g} / \mathrm{ml}$ of $\mathrm{AMROH}$ were analyzed. All survival curves were flat, i.e., cell phase responses were not seen regardless of the concentrations of AMR or AMROH. We reported that bleomycin (29), which inhibits DNA synthesis, was cell cycle non-specific regardless of concentration (30). When exposed to more than moderate hyperthermia or radiation, cells are most sensitive to hyperthermia during the $\mathrm{G}_{1}-\mathrm{S}$ phase and to radiation during the $\mathrm{G}_{2}-\mathrm{M}$ phase $(50,51)$. There was no cell phase response to mild hyperthermia that could be assessed uniformly in all phases for thermosensitivity (30), but with $44^{\circ} \mathrm{C}$ experimental 
hyperthermia, sensitivity was high during the $G_{1}-S$ phase (31). While various studies have been conducted to determine the target of hyperthermia, no conclusive evidence has been obtained. The reason that chemicals such as AMR in Fig. 4 and BLM lack cell phase responses may be due to the fact thit they target different types of DNA damage (52-54). Hence, more effective synergism may be achieved by combined treatment with hyperthermia and drug administration, as the mirror contrast on each cell phase response, in order (o) enhance and complement antitumor effects.

Induction of apoptosis and necrosis. The induction of apoptosis following $44^{\circ} \mathrm{C}$ hyperthermia or $0.02 \mu \mathrm{g} / \mathrm{ml}$ AMROH increased slightly with time, but there was no significant increase following sequential combination therapy. However. the induction of necrosis following $44^{\circ} \mathrm{C}$ hyperthermia increased with time, and there was a significant increase in the induction of necrosis after $4 \mathrm{~h}$ of AMROH exposure followed by $44^{\circ} \mathrm{C}$ hyperthermia. p53-mediated apoptosis is thought to be cell cycle dependent $(55,56)$. We reported that apoptosis was induced cffectively by $44^{\circ} \mathrm{C}$ hyperthermia in thermosensitive murine $\mathrm{L}$ cells with wild-type $\mathrm{p} 53$ (8). The results of the present study were unexpected in that the cytotoxicity of AMROH against A549 cells having wild-type p53 in hyperthermia wals due to increased necrosis, not increased apoptosis. In addition, with A549 cells, cell phase responses were not seen. This suggests that AMR and AMROH directly act on DNA topoisomerase II without affecting the p53 cascade. AMR and AMROH were shown to dynamically enhance the thermosensitivity of A549 cells. Thus, in multidisciplinary anticancer therapy, the antitumor effects of hyperthermia can be improved by administering AMR or its metabolite, AMROH (57).

\section{Acknowledgements}

This study was supported in part by Grant-in-Aid of the Ministry of Education, Science and Culture, Japan, for scientific research (C)-2, No. 16591196 (Mechanism of radio-enhancement effect by topoisomerase II inhibitot in human lung carcinoma cells) 2004-2006.

\section{References}

1. Noguchi T, Ichii S, Morisada S, Yamaoka T and Yanagi Y: In vivo efficacy and tumor-selective metabolism of amrubicin to its active metabolite. Jpn J Cancer Res 89: 1055-1060, 1998.

2. Noguchi T, Ichii S, Morisada S, Yamaoka T and Yanagi Y: Tumor-selective distribution of an active metabolite of 9aminoanthracycline amrubicin. Jpn J Cancer Res 89: 1061-1066, 1998.

3. Ogaw: M: Novel anticancer drugs in Japan. J Cancer Res Clin Oncol 125: 134-140, 1999.

4. Yamaoka T, Hanada M, Ichii S, Morisada S, Noguchi T and Yanagi $Y$ : Cytotoxicity of amrubicin, a novel 9-aminoanthracycline, and its active metabolite amrubicinol on human tumor cells. Jpn J Cancer Res 89: 1067-1073, 1998.

5. Morisada S, Yanagi Y, Noguchi T, Kashiwazaki Y and Fukui M: Antitumor activities of a novel 9-aminoanthracycline (SM-5887) against mouse experimental tumors and human (umor xenografts. Jpn J Cancer Res 80: 69-76, 1989.

6. Hanada M, Mizuno S, Fukushima A, Saito Y, Noguchi T and Yamaoka T: A new antitumor agent amrubicin induces cell growth inhibition by stabilizing topoisomerase II-DNA complex. Jpn J Cancer Res 89: 1229-1238, 1998.
7. Yamauchi S, Kudoh S. Kimura T, Hirata K and Yoshikawa J: Additive effects of amrubicin with cisplatin on human lung cancer cell lines. Osaka City Med J 48: 69-76, 2002.

8. Hayashi S, Kano E, Matsumoto $H$, Hatashita M, Ohtsubo T, Nishida T. Shioura H and Kitai R: Thermosensilivity, incidence of apoptosis and accumulations of hsp72 and p53 proteins of murine L cells in wild-type status of p53 gene. J Exp Clin Cancer Res 18: 181-189, 1999.

9. Henle KJ and Dethletsen LA: Heat fractionation and thermololerance: a review. Cancer Res 38: 1843-1851, 1978.

10. Jung $\mathrm{H}$ and Kolling $\mathrm{H}$ : Induction of thermotolerance and sensitization in $\mathrm{CHO}$ cells by combined hyperthermic treatments at 40 and $43^{\circ} \mathrm{C}$. Eur J Cancer 16: 1523-1528, 1980.

11. Hilyashi S. Kano E, Tsuji K, Furukawa-Furuya M, Yoshikawa S, Hatashita $\mathrm{M}$. Matsumoto $\mathrm{H}$, Jin Z, Ohtsubo $\mathrm{T}$ and Kitai R: Modification of thermosensitivity and chemosensitivity induced by combined treatments with hyperthermia and adriamycin. Int J Nol Med 8: 417-422. 2001

12. Giard DJ, Aaronson SA, Todaro GJ, Arnstein P, Kersey JH, Dosik $\mathrm{H}$ and Parks WP: In vitro cultivation of human tumors: establishment of cell lines derived from a series of solid tumors. J Natl Cancer lins 51: 1417-1423, 1973.

13. Licber M, Smith B, Szakal A, Nelson-Rees W and Todaro G: A continuous tumor-cell line from a human lung carcinoma with properties of type II alveolar epithelial cells. Int J Cancer 17: $62-70,1976$.

14. Coco-Martin JM, Smeets MF, Poggensee M, et al: Use of fluorescence in situ hybridization to measure chromosome aberrations as a predictor of radiosensitivity in human tumour cells. Int J Radiat Biol 66: 297-307, 1994.

15. Harari PM. Fuller DJ. Carper SW, Croghan MK, Meyskens FL Jr, Shimm DS and Gerner EW: Polyamine biosynthesis inhibitors combined with systemic hyperthermia in cancer therapy. Int J Radiat Oncol Biol Phys 19: 89-96, 1990.

16. Armour EP, McEachern D, Wang Z, Corry PM and Martinez A: Sensitivity of human cells to mild hyperthermia. Cancer Res 53: 2740-2744, 1993.

17. Furuta M. Tsukiyama 1 and Kano Y: Simultaneous intraluminal thermobrachytherapy: an in vitro sludy. Jpn J Cancer Res 92: 904-910, 2001.

18. Vilenzuela DM and Groffen J: Four human carcinoma cell lines with novel mutations in position 12 of $\mathrm{c}-\mathrm{K}$-ras oncogene. Nucleic Acids Res 14: 843-852, 1986.

19. Noble JR, Willetts KE, Mercer WE and Reddel RR: Effects of exogenous wild-lype p53 on a human lung carcinoma cell line with endogenous wild-type p53. Exp Cell Res 203: 297-304, 1992.

20. Yonish-Rouach E, Resnitzky D, Lotem J, Sachs L, Kimchi A and Oren M: Wild-lype p53 induces apoptosis of myeloid leukaemic cells that is inhibited by interleukin-6. Nature 352 : 345-347. 1991.

21. Shaw P, Bovey R. Tardy S, Sahli R, Sordat B and Costa J: Induction of apoptosis by wild-type p53 in a human colon tumorderived cell line. Proc Natl Acad Sci USA 89: 4495-4499, 1992.

22. Martinez J, Georgoff I, Martinez J and Levine AJ: Cellular localization and cell cycle regulation by a temperature-sensitive p53 protein. Genes Dev 5: 151-159, 1991.

23. Kuerbitz SJ. Plunketl BS, Walsh WV and Kastan MB: Wildtype p53 is a cell cycle checkpoint determinant following irradiation. Proc Natl Acad Sci USA 89: 7491-7495, 1992.

24. Sionov RV and Haupt $\mathrm{Y}$ : The cellular response to p53: the decision between life and death. Oncogene 18: 6145-6157, 1999.

25. Vousden KH: p53: death star. Cell 103: 691-694, 2000.

26. Lowy DR and Willumsen BM: Function and regulation of ras. Amnu Rev Biochem 62: 851-891, 1993.

27. Kaziro $Y$, Itoh H, Kozasa T, Nakafuku $M$ and Satoh T: Structure and function of signal-transducing GTP-binding proteins. Annu Rev Biochem 60: 349-400, 1991.

28. McBride OW, Swan DC, Tronick SR, Gol R, Klimanis D, Moore DE and Aaronson SA: Regional chromosomal localization of $\mathrm{N}$-ras, K-ras-1, K-ras-2 and myb oncogenes in human cells. Nucleic Acids Res 11: 8221-8236, 1983.

29. Hishimoto $Y$, lijima $\mathrm{H}$ and Shudo K: Functional analogs of bleomycin: sequence-specific DNA cleavage with porphyrin (Fe) intercalators. Gann 75: 567-570, 1984.

30. Shioura H, Hayashi S, Matsumoto H, Kitai R, Ohtsubo T, Nishida T, Zhang SW, Yoshida M, Ishii $Y$ and Kano E: The effects of combined treatments with low hyperthermia and bleomycin on survivals of murine $\mathbf{L}$ cells. J Exp Clin Cancer Res 16: 147-152, 1997. 
31. Westra A and Dewey WC: Variation in sensitivity to heat shock during the cell-cycle of Chinese hamster cells in vitro. Int $\mathrm{J}$ Radiat Biol Relat Stud Phys Chem Med 19: 467-477, 1971.

32. Kerr JF, Wyllie AH and Currie AR: Apoptosis; a basic biological phenomenon with wide-ranging implications in tissue kinetics. Br J Cancer 26: 239-257, 1972.

33. Khodarev NN, Sokolova IA and Vaughan AT: Mechanisms of induction of apoptotic DNA fragmentation. Int J Radiat Biol 73: 455-467, 1998.

34. Allan DJ and Harmon BV: The morphologic categorization of cell death induced by mild hyperthermia and comparison with death induced by ionizing radiation and cytotoxic drugs. Scan Electron Microsc (PL 3): 1121-1133, 1986.

35. Cho KS, Lee EH, Choi JS and Joo CK: Reactive oxygen species-induced apoptosis and necrosis in bovine corneal endothelial cells. Invest Ophthalmol Vis Sci 40: 911-919, 1999.

36. Young $\mathrm{CW}$ and Hodas S: Hydroxyurea: Inhibitory effect on DNA metabolism. Science 146: 1172-1174, 1964.

37. Sinclair WK: Hydroxyurea: differential lethal eflects on cultured mammalian cells during the cell cycle. Science 150: 1729-1731, 1965.

38. Leite M, Quinta-Costa M, Leite PS and Guimaraes JE: Critical evaluation of techniques to detect and measure cell death - study in a model of UV radiation of the leukaemic cell line HL60. Anal Cell Pathol 19: 139-151, 1999.

39. Wang JC: DNA topoisomerases. Annu Rev Biochem 54: 665-697, 1985.

40. Wang JC: Recent studies of DNA topoisomerases. Biochim Biophys Acta 909: 1-9, 1987.

41. Kelly TJ: SV40 DNA replication. J Biol Chem 263: 17889-17892, 1988.

42. Nelson EM, Tewey KM and Liu LF: Mechanism of antitumor drug action: poisoning of mammalian DNA topoisomerase II on DNA by 4'-(9-acridinylamino)-methanesulfon-m-anisidide. Proc Natl Acad Sci USA 81: 1361-1365, 1984.

43. Liu LF: DNA topoisomerase poisons as antitumor drugs. Annu Rev Biochem 58: 351-375, 1989.

44. Kampinga $\mathrm{HH}:$ Hyperthermia, thermotolerance and topoisomerase II inhibitors. Br J Cancer 72: 333-338, 1995.

45. Ohtsubo T, Kano E, Ueda K, Matsumoto H, Saito T, IJayashi S, Hatashita M, Jin Z and Saito H: Enhancement of heat-induced heat shock protein (hsp) 72 accumulation by doxorubicin (Dox) in vitro. Cancer Lett 159: 49-55, 2000.
46. Ohtsubo T. Saito H, Matsumoto H, Hayashi S, Shioura H, Kitai R, Sailo T and Kano E: In vitro effects of hyperthermia combined with cisplatin or peplomycin on the human maxillary carcinoma cell line IMC-2. Int J Hyperthermia 13: 59-67, 1997.

47. Matsumoto H. Hayashi S, Shioura H, Ohtsubo T, Kitai R, Ohnishi K. Hayashi N. Ohnishi T and Kano E: Suppression of heal-induced HSF activation by CDDP in human glioblastoma cells. Int J Radiat Oncol Biol Phys 41: 915-920, 1998.

48. Arcamone F. Franceschi G. Penco S and Selva A: Adriamycin (14-hydroxydaunomycin), a novel antitumor antibiotic. Tetrahedron Lett 13: 1007-1010, 1969.

49. Gensler WJ and Gatsonis CD: The podophyllotoxinpicropodophyllin equilibrium. J Org Chem 31: 3224-3227, 1966.

50. Sinclair WK and Morton RA: X-ray sensitivity during the cell generation cycle of cultured Chinese hamster cells. Radiat Res 29: 450-474, 1966.

51. Withers HR, Mason K. Reid BO, Dubravsky N, Barkley HT Jr, Brown BW and Smathers JB: Response of mouse intestine to neutrons and gamma rays in relation to dose fractionation and division cycle. Cancer 34: 39-47, 1974.

52. Kobayashi E. Yamagishi M, Kamamoto T, Yoshida Y and Uchino 11: Cell cycle-dependent heat sensitization of murine granulocyte-macrophage progenitor cells in regenerating marrow. Cancer Res 45: 1459-1463, 1985.

53. Kanno S, Hyodo M, Suzuki K and Ohkido M: Effect of DNAdamaging agents on DNA replication and cell-cycle progression of cultured mouse mammary carcinoma cells. Jpn J Cancer Res 76: $289-296,1985$.

54. Olive PL and Banath JP: Detection of DNA double-strand breaks through the cell cycle after exposure to X-rays, bleomycin, etoposide and ${ }^{125}$ IdUrd. Int J Radiat Biol 64: $349-358,1993$

55. Ryan JJ, Danish R, Gottlieb CA and Clarke MF: Cell cycle analysis of p53-induced cell death in murine erythroleukemia cells. Mol Cell Biol 13: 711-719, 1993.

56. Yonish-Rouach E, Grunwald D, Wilder S, Kimchi A, May E, Lawrence JJ, May P and Oren M: p53-mediated cell death: Relationship to cell cycle control. Mol Cell Biol 13: 1415-1423, 1993.

57. Eutinger DS: New drugs for chemotherapy-naive patients with extensive-disease small cell lung cancer. Semin Oncol 28 (Suppl 4): 27-29.2001. 